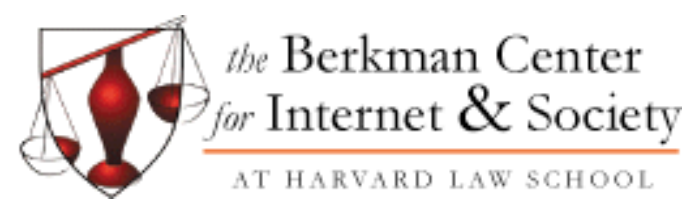

Research Publication No. 2006-10

August 2006

\title{
Teaching Exceptions in European Copyright Law - Important Policy Questions Remain
}

\author{
Silke Ernst \& Daniel M. Haeusermann
}

This paper can be downloaded without charge at:

The Berkman Center for Internet \& Society Research Publication Series:

http://cyber.law.harvard.edu/publications

The Social Science Research Network Electronic Paper Collection:

http://papers.ssrn.com/abstract_id=XXXXXX 


\title{
TEACHING EXCEPTIONS IN EUROPEAN COPYRIGHT LAW - IMPORTANT POLICY QUESTIONS REMAIN ${ }^{\dagger}$
}

\author{
Silke Ernst \& Daniel M. Haeusermann* \\ (under the direction of Urs Gasser ${ }^{* *}$ )
}

\begin{abstract}
The paper seeks to explore the implementation of the EU Copyright Directive (EUCD) provisions on research and teaching in selected Member States using a fictitious case study of a professor who scans parts of a textbook, copies some digital articles, uploads them to the university's web server and gives passwords to the students enrolled in his class. After a rough clustering of country-specific implementations, the permissibility of the uses made in the case scenario is explored under five representative jurisdictions: Denmark, Germany, Luxemburg, Malta, and Slovenia. Finally, the authors raise a couple of policy questions that emanate from the previous analysis.
\end{abstract}

Keywords: $\quad$ European Copyright Directive - Education - eLearning - Comparative law

$\dagger \quad$ This paper is a slightly revised version of a study conducted in the course of the Berkman project which resulted in the white paper "The Digital Learning Challenge: Obstacles to Educational Uses of Copyrighted Material in the Digital Age”, available at http://cyber.law.harvard.edu/media/files/copyrightandeducation.html. A linklist to the cited copyright laws is available at http://cyber.law.harvard.edu/media/eucd materials. All sources as of June 8, 2006.

* Researchers and SJD candidates at the Research Center for Information Law, University of St. Gallen (Switzerland).Email: silke.ernst@unisg.ch, daniel.haeusermann@unisg.ch.

** Director, Research Center for Information Law, University of St. Gallen; Faculty Fellow, Berkman Center for Internet \& Society, Harvard Law School. 


\title{
TEACHING EXCEPTIONS IN EUROPEAN COPYRIGHT LAW - IMPORTANT POLICY QUESTIONS REMAIN
}

\author{
Silke Ernst \& Daniel M. Haeusermann
}

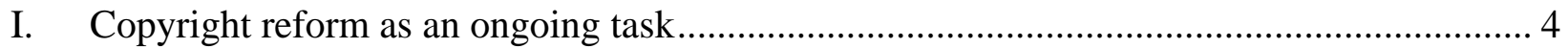

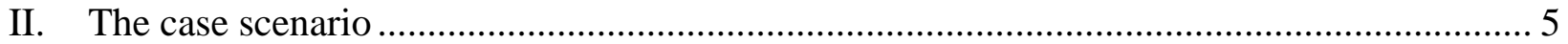

III. Legal framework and prima facie analysis ............................................................. 5

1. Relevant EUCD provisions ............................................................................ 5

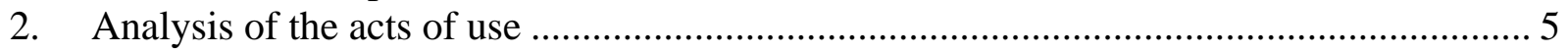

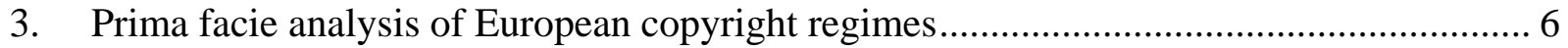

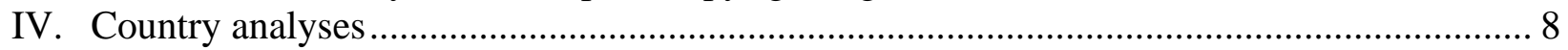

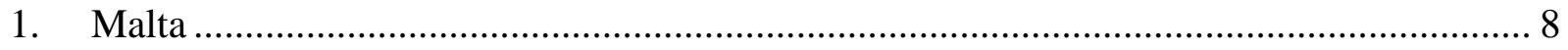

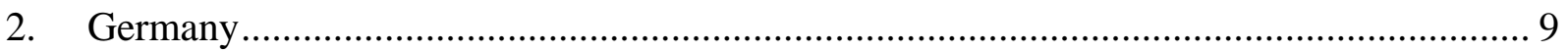

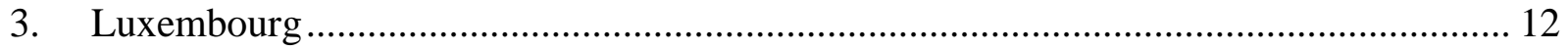

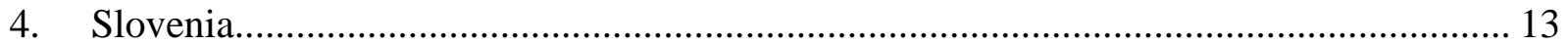

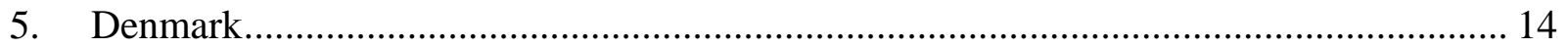

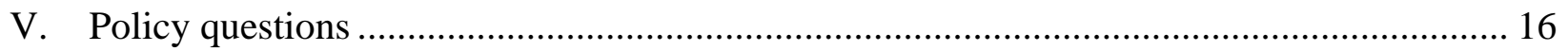

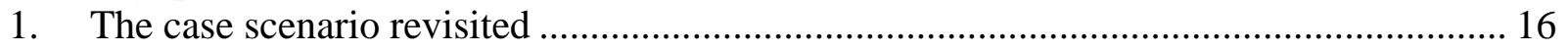

2. Do the implementations achieve sufficient legal certainty? ........................................ 16

3. Did the EUCD achieve its goal to harmonize copyright law? .................................... 17

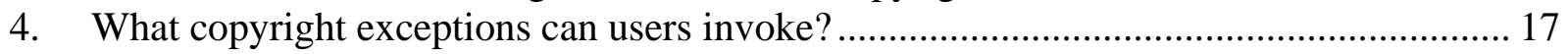

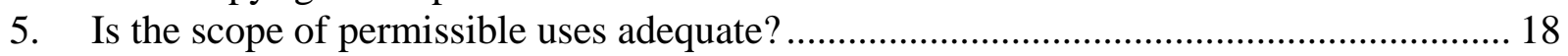

6. How effective are the legal techniques of transposition? ............................................ 18

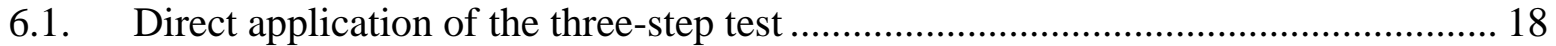

6.2. Fair dealing and statutory exceptions ........................................................ 19

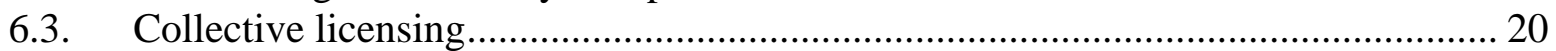

7. What role do and should technical protection measures play? .................................... 20

VI. Devising teaching exceptions as a continuing challenge ........................................... 21 


\section{COPYRIGHT REFORM AS AN ONGOING TASK}

Since the publication of the EU Copyright Directive ${ }^{1}$ in 2001, five years have elapsed. To date, most EU members have implemented the EUCD, though lengthy public debates, as for example in Germany, have slowed down the process of transposition. ${ }^{2}$ In Spain, the implementation bill is still pending, ${ }^{3}$ and France has implemented the directive only very recently. ${ }^{4}$ Since 2001, the information society has seen further evolution, and the use of digital media and the internet has become part of everyday life at schools and universities ${ }^{5}$.

(European) policy makers faced with these developments now have the possibility of striking an interim balance from the reform efforts. In an ongoing process of evolving technologies and changing research ${ }^{6}$ and teaching habits, this is an opportunity to reorientate and single out the new challenges posed to education and research by the recently reformed copyright regimes. By comparing selected national transpositions of the EUCD we seek to identify some policy issues for such a stocktaking ${ }^{7}$.

Our research approach is thus two-tiered: In a first step, we present the spectrum of national implementations of the EUCD in order to illustrate the status quo as to teaching and research exceptions in Europe. For that purpose, we will apply the copyright laws of selected member states to a fictitious case study (sec. 2 - 4). In a second step, we will-in a very cursory manner-identify a bunch of policy questions that emanate from our analysis of the status quo (sec. 5). The normative background of this will be the needs for modern forms of higher education, as depicted in our case scenario.

1 Directive 2001/29/EC of the European Parliament and of the Council of May 22, 2001 on the harmonisation of certain aspects of copyright and related rights in the information society, available at http://ec.europa.eu/ information_society/eeurope/2005/all_about/digital_rights_man/doc/directive_copyright_en.pdf.

2 On March 22, 2006, the German Federal Government presented a proposal for the second part of copyright reform ("second basket"). The proposed amendments to the German Copyright Act of 1965 affect the conditions for teaching and research mainly by introducing new exceptions for libraries, (in German) available at http://www.kopien-brauchen-originale.de/media/archive/139.pdf.

3 A new draft was published by the Spanish Congress of Deputies in October 2005. Cf. also commentary by Judit Rius Sanjuan, May 15, 2006, http://www.secondview.blogspot.com/.

4 At the time when the main part of the study was composed, the French implementation bill ("Projet de loi relatif au droit d'auteur et aux droits voisins dans la société de l'information” - short: DADVSI) was still pending. The law was finally promulgated on August 1, 2006: http://www.legifrance.gouv.fr/WAspad/UnTexteDeJorf? numjo $=$ MCCX0300082L

5 Take for example the new forms of teaching (e.g. MIT Open Course Ware ${ }^{5}$ ) or new forms of publication (e.g. Budapest Open Access Initiative (2001) and Berlin declaration of Open Access of 2003)).

6 For a general description of the changes in science, see David Kellogg, Toward a Post-Academic Science Policy: Scientific Communication and the Collapse of Mertonian Norms, preprint draft of April 14, 2006, available at http://papers.ssrn.com/sol3/papers.cfm?abstract_id=900042.

7 The ambition to foster teaching, research and innovation is declared, e.g., in the relaunch of the Lisbon Agenda, European Commission, COM (2005) 24, p. 9 available at http://europa.eu.int/growthandjobs/pdf/ COM2005 024_en.pdf or in the European Cooperation in the field of Scientific and Technical Research (COST), information available at http://www.cost.esf.org/ index.php. 


\section{THE CASE SCENARIO}

The following is a typical situation within an institution of higher education:

An economics professor at a public university in Europe has decided to compile a number of texts for an upcoming seminar on regional microeconomic case studies. Working from his own office library, he 1) digitally scans a twenty page excerpt from a 400-page textbook and 2) downloads various research articles from a scientific database. He stores both the excerpt and the articles on his workstation's hard drive. Finally, he uploads the scanned file and electronic copies of the articles on his university's web server and gives passwords to the students enrolled in his class, so that they can access the materials from their personal computers at home. ${ }^{8}$

\section{LEGAL FRAMEWORK AND PRIMA FACIE ANALYSIS}

\section{Relevant EUCD provisions}

Two provisions of the EUCD may be relevant to our scenario: The first one is Art. 5(2)c EUCD, allowing member states to provide for exceptions or limitations to the reproduction right (Art. 2 EUCD),

"in respect of specific acts of reproduction made by publicly accessible libraries, educational establishments or museums, or by archives, which are not for direct or indirect economic or commercial advantage".

The second provision is Art. 5(3)a EUCD, under which member states may provide for exceptions or limitations to the reproduction right and the right to make works available (Art. 2 and 3 EUCD) in the case of:

"use [of a work] for the sole purpose of illustration for teaching or scientific research, as long as the source, including the author's name, is indicated, unless this turns out to be impossible and to the extent justified by the non-commercial purpose to be achieved”.

\section{Analysis of the acts of use}

In order to apply the national implementations of the EUCD, the legally relevant uses need to be extracted from the case scenario ${ }^{9}$, that is, uses which constitute either reproduction (Art. 2 EUCD) or making a work available to the public as a subordinate right of communicating it to the public (Art. 3 EUCD). In order to carry out his work legally, the professor needs to be able to invoke a statutory exception to copyright for each one of the identified steps or, absent such limitation, obtain the permission from the rightsholder. We suggest dividing the acts into the following steps:

8 The acts of the students who will subsequently download and save the papers, i.e. the question whether they can invoke the right to make a private copy, will be disregarded in the analysis.

9 Generally, the legally relevant acts can only be determined on the basis of each national copyright regime. However, for the sake of comparability we use this chronology of acts as a timeline. 


\begin{tabular}{|c|c|c|c|c|}
\hline 1 & 21 & 3 & 4 & \\
\hline $\begin{array}{c}\text { Scanning of } \\
20 \text { out of } 400 \\
\text { pages }\end{array}$ & $\begin{array}{l}\text { Storing copies of } \\
\text { research articles } \\
\text { and scanned } \\
\text { pages on his } \\
\text { hard-drive }\end{array}$ & $\begin{array}{l}\text { Uploading of } \\
\text { scans and } \\
\text { articles to the } \\
\text { university's } \\
\text { web server }\end{array}$ & $\begin{array}{l}\text { Enabling en- } \\
\text { rolled students to } \\
\text { access (and } \\
\text { copy) the works } \\
\text { via passwords }\end{array}$ & \\
\hline
\end{tabular}

\section{Prima facie analysis of European copyright regimes}

A prima facie analysis of the implementations of the EUCD's teaching provisions ${ }^{10}$ revealed a number of similar patterns in the legislative techniques and in the definition of the permissible scope of use. Thus, we suggest that the implementations be categorized into three superclusters, based on the legislative technique used. The super-cluster consisting of countries which have chosen statutory exceptions in favor of teaching and research can be divided into four subclusters, depending on the scope of permissible uses. The suggested clustering allows us to focus on one example for each cluster in section 4's country-specific analysis.

\section{a) Statutory exceptions}

- The first sub-cluster consists only of Malta. ${ }^{11}$ This EU member implemented the directive almost literally. Since the copyright limitations of Art. 5(2) and (3) EUCD are not mandatory, its literal implementation is likely to represent the most permissive copyright regime for research and teaching possible for E.U. members.

- The second sub-cluster consists of Belgium, ${ }^{12}$ Germany, ${ }^{13}$ Greece, ${ }^{14}$ Hungary, ${ }^{15}$ and Lithuania. ${ }^{16}$ These copyright regimes have in common a wording that allows for reproduction of articles and short excerpts of books. We will portray the German implementation because of the rich literature on the interpretation of the exception.

10 Several national implementations such as Finland, Poland, the Netherlands and Cyprus were not considered, as no English, French or German translation was available. France was not considered because the implementation bill was pending in the French Senate when the main part of the study was composed (see supra, note 4). The copyright regimes of Spain and the Czech Republic were not considered either, due to their lack of (full) implemenation. See also for information on the infringement proceedings against France, Finland, Spain and the Czech Republic for non-implementation of the EUCD, Press Release of July 13, 2005, IP/05/921, available at http://europa.eu.int/rapid/pressReleasesAction.do?reference=IP/05/921\&format=HTML\&aged=1\&language=E $\underline{N}$ \&guiLanguage $=$ en. The European Commission also sent a reasoned opinion to Spain according to a press release on April 19, 2006 because it has not yet communicated the status of its national legislation, available at http://europa.eu.int/rapid/pressReleasesAction.do?reference=IP/06/503\&format=HTML\&aged=0\&language=E N\&guiLanguage $=$ en.

11 Malta Copyright Act XIII of 2000, as amended by Acts VI of 2001 and IX of 2003.

12 Belgium Copyright of June 30, 1994 as amended by the Act of May 22, 2005, see Art. 22, 1er, $4^{\circ}$ ter and quarter.

13 German Copyright Act as amended on September 10, 2003, Section 52a.

14 Greece: Copyright, Related Rights and Cultural Matters of 1993 as amended on October 10, 2002 , Art. 21.

15 Hungarian Copyright Act (Act No. LXXVI of 1999 on Copyright), enacted on May 1, 2004, Art. 34.

16 Lithuanian Law amending the law on Copyright and Related Rights, March 5, 2003, see Art. 22 (1) no. 1. 
- Another sub-cluster consists of Luxembourg, Portugal and Slovakia, which allow the reproduction and making available to the public of short excerpts of works. ${ }^{17}$ Luxembourg was chosen because the Luxembourgian Copyright Act is available in its official French version.

- The fourth sub-cluster, consisting of Estonia ${ }^{18}$ and Slovenia ${ }^{19}$, can be characterized by their restrictiveness vis-à-vis the use of information technology in education. Slovenia was chosen as the more restrictive jurisdiction combining a restrictive approach towards making works available to the public and a very narrow copying exception for educational purposes.

\section{b) Collective licensing}

- The next cluster comprises all copyright regimes that provide for collective licenses to govern the use of copyrighted works in education and research. We grouped Denmark, ${ }^{20}$ Ireland, ${ }^{21}$ Sweden ${ }^{22}$ and the United Kingdom ${ }^{23}$ in this cluster. From this group, we will examine Denmark in further detail, since it follows a model of collective licensing typical for northern Europe.

\section{c) Transparency}

- The last cluster consists of copyright laws whose provisions are-from our perspective-not clear enough to permit us to analyze them without being too speculative. This cluster consists of Latvia, ${ }^{24}$ Austria, ${ }^{25}$ and Italy. ${ }^{26}$ Consequently, no country from this cluster will be portrayed.

These clusters are by no means imperative, however. ${ }^{27}$ Other factors such as the obligation to pay remuneration or a grouping according to common law and civil law tradition could have been taken into consideration as well and may have painted a different picture. However, the suggested clusters seem to be adequate for sorting out the different practical problems that evolve from the recently reformed national copyright regimes and can point toward areas of future policymaking.

17 See 10.2 Luxembourg Copyright Act; Portugese Copyright Act as amended on August 24, 2004, Lei n. ${ }^{\circ}$ 50/2004, Section 75.2 (f); Slovakian Copyright Act of December 4 ${ }^{\text {th }}$, 2003, Section 28 (1).

18 Official title: Autorioiguse Seaduse Muutmise Seadus, as amended September 22, 2004, see Art. 19 (2).

19 Slovenian Copyright and Related Rights Act of 30 March 1995 (as amended last on February 17, 2006), see Art. 50.

20 Danish Consolidated Act on Copyright as amended on March 12, 2003, Section 13 (1), 50.

21 Irish Copyright and Related Rights Act, 2000, as amended on January 19, 2004, Section 57, 173, 50 (3)a.

22 Swedish Copyright Legislation as amended up to July 1, 2005, see Articles 42c.

23 United Kingdom Copyright, Designs and Patents Act 1988 as amended December 31st, 2003, see Sections 32, 36,116 et seq.

24 Latvian Copyright Law as amended March 6, 2003, April 22, 2004, Chapter V, Section 18-35, esp. section 21.

25 Bundesgesetz über das Urheberrecht an Werken der Literatur und der Kunst und über verwandte Schutzrechte, StF: BGBl. Nr. 111/1936 i.d.F. der UrhG-Novelle 2003, esp. Sections 42 (6), 45 (1) no.2.

26 Italian Copyright Statute, Law No. 633 of April 22, 1941 as last amended by Legislative Decree No. 68, of April 9, 2003, Exceptions and Limitations in Chapter 5, Sect. I. Art. 65- 71quinquies.

27 Others have made different clusters: see e.g. throughout her analysis, Raquel Xalabader, Copyright Exceptions for teaching purposes in Europe, July 2004, pp.25- 28, available at http://www.uoc.edu/in3/dt/eng/20418/ 20418.pdf. 


\section{COUNTRY ANALYSES}

In the following country analyses, the requirement set out by Art. 5(3)a EUCD relating to author attribution is not examined in each case because all countries adhere to this requirement. ${ }^{28}$

\section{Malta}

\section{General}

Malta is the only country which has transposed Art. 5 EUCD almost literally. ${ }^{29}$ Sec. 9(1)h Copyright Act states that copyright (inter alia) in a literary work shall not include the right to authorize or prohibit:

"the reproduction, translation, distribution or communication to the public of a work for the sole purpose of illustration for teaching or scientific research only to the extent justified by the noncommercial purpose to be achieved, and as long as the source, including the author's name, is, unless this is impossible, indicated."

The only material difference from Art. 5(3)a EUCD is that the latter only limits the rights of reproduction (Art. 2 EUCD) and communication to the public respectively (Art. 3 EUCD), but not the right to distribute copies of works or to translate them. As far as our example is concerned, however, the scope of the exception is the same.

Like Art. 5(3)a EUCD, sec. 9(1)h Copyright Act is subject to the three step test (sec. 9(3) Maltese Copyright Act, Art. 5(5) EUCD).

\section{Acts of usage}

According to sec. 2 of the Maltese Copyright Act, "reproduction” means the making of copies in any material form, including digital reproductions and storing copies electronically. Thus, there is no distinction between the scanning of parts of a textbook and the copying of digital articles; both fall within the acts of usage permitted by sec. 9(1)h Copyright Act. Uploading the digital materials to a web server involves an act of copying, too. Enabling students to access the materials on a password protected website can be subsumed under the term "communication to the public", which comprises the making available of works on the world wide web (cf. sec. 2 Copyright Act). Thus, all acts performed by the professor are covered by sec. 9(1)h Copyright Act.

As to the purpose of the acts in question, it is not clear whether they are for the purpose of "illustration for teaching" or "scientific research". However, the distinction has no practical implications, as sec. 9(1)h Copyright Act, like its EUCD counterpart, cover both purposes. Furthermore, acts permitted under sec. 9(1)h must not exceed the limits of what is justified by their non-commercial purpose. It is evident that the user-or the judge-has a considerable margin of discretion in this respect, which does not seem to be exceeded in our particular case.

To sum up, the specific conditions of sec. 9(1)h Copyright Act are fulfilled.

28 See Sec. 9 (1) h Maltese Copyright Act, Section 63 (2) German Copyright Act, Art. 47 (3) Slovenian Copyright Act, Art. $102^{\circ}$ Luxembourgian Copyright Act. Denmark only refers to the collective license in Section 13 (1) Danish Copyright Act, it is thus up to the rightsholders to insist on attribution.

29 Sec. 9(1)a of the Maltese Copyright Act of 2000 (Cap. 415) corresponds to Art. 5(1) EUCD; sec. 9(1)b-f correspond to Art. 5(2) EUCD; sec. 9(1)h-o and q-v correspond to Art. 5(3) EUCD; sec. 9(3) corresponds to the three step test of Art. 5(5) EUCD. Sec. 9(1)g and p can be subsumed under the "de minimis" exception of Art. 5(3)o EUCD, but are not of direct relevance to teaching and research. 


\section{Three-step test}

Yet the uses in question must also pass the three step test of sec. 9(3) Copyright Act, which requires that the exceptions to copyright should only be applied (a) in particular cases, (b) which do not conflict with a normal exploitation of the work and (c) do not unreasonably prejudice the legitimate interests of the rightsholder. ${ }^{30}$ Unfortunately, this test is very vague and overlays the much more concrete conditions of Art. 9(1)h Copyright Act: For instance, if the publisher allows chapter-by-chapter downloads of the textbook for a fee, the usage made by the professor could be seen as conflicting with the normal exploitation of the works. Hence, it is hard to predict how a Maltese court would interpret the three-step test in this particular case.

\section{Collective administration of rights}

Malta has repealed most of the provisions regarding the collective administration of rights when it implemented the EUCD: Now, the only provision in this respect (sec. 52 Copyright Act) stipulates that rightsholders may authorize a collecting society to administer their economic rights. Thus, there is no collective administration of rights which is also binding for rightsholders, such as levies on electronic devices or storage media. Hence, the acts performed by our professor would be free of charge, if they are covered by the statutory teaching and research exception.

\section{Conclusion}

The problem with an almost literal transposition of Art. 5(2)-(3) EUCD lies in the threestep test: Vague in its nature, it is likely to have a chilling effect on users. Hence, a literal transposition of Art. 5(2)-(3) EUCD has the great disadvantage that the three step test must be implemented additionally and separately since otherwise the scope of exceptions would be in violation of Art. 5(5) EUCD ${ }^{31}$.

\section{Germany}

General

The German Copyright Act from 1965 as amended by September 10, 2003, states in Section 52a (1) no. 1 the permissibility of

"making available to the public small portions of published works, other short works, or individual contributions to newspapers or periodicals, exclusively for purposes of illustration for teaching, for students and other participants in instruction in schools, universities, post-secondary institutions, and noncommercial career-training institutions. Access must be restricted to a limited circle of participants. ${ }^{, 32}$

30 For some suggestions as to the interpretation of the three step test within the context of research and teaching, see Xalabader, supra note 30, pp. 25-28.

31 See e.g., Martin Senftleben, Copyright, Limitations and the three-steps test, 2004, 269, 277.

32 Translation derived from Kenneth D. Crews/ Jacques Ramos, Comparative Analysis of International Copyright Law Applicable to University Scholarship, Draft: November 10, 2004, available at http://www.surf.nl/ copyright/International_Comparative_Chart_ZwolleIII_1104.pdf. Emphasis added. 
Section 52a (1) no. 2 of the German Copyright act allows the

"making available to the public to a limited circle of participants of portions of works, other short works and or individual contributions to newspapers and periodicals exclusively for purposes of own research., ${ }^{33}$

According to Section 52a (3) of the German Copyright Act, the necessary reproductions for the purpose of making a work available in subsection (1) no. 1-2 are permissible as well. Section 52a (4) of the Act imposes an obligation on the users to pay a remuneration for making a copyrighted work available. The payment is collected through a collective licensing society.

\section{Permissibility of scanning, storing and uploading}

The activities 1) to 3) of the professor could be subsumed under Section 52a (3) German Copyright Act, provided that the scanning of the twenty pages and the storing of the articles on the hard drives are reproductive acts according to the definition in Section 16 (1) German Copyright Act: The latter does not differentiate between analog and digital reproductions, but only refers to the multiplication of a work irrespective of the technical procedure. ${ }^{34}$ Therefore, the scanning and subsequent storing on the hard drive and on the server are reproductive acts within the meaning of Sec. 16(1). If it is permissible to give students access to the files under Section $52 \mathrm{a}(1)$ or (2) German Copyright Act, the reproductive acts in question are automatically permitted as well, according to Sec. 52(3).

\section{Permissibility of making available}

Our next step is to analyze whether the acts of giving students access to the files on the server is permissible under Section 52a (1) of the German Copyright Act. Here, the law states several prerequisites:

a) First of all, only small portions of a work may be reproduced and made available, unless only a small work is concerned. ${ }^{35}$

As regards the textbook, we thus have to test whether 20 pages of a 400-page book exceed this allowable proportion. As a 400-page book is no small work, the question is whether 5 $\%$ of a book constitute a small portion of a work. German case law refers to a fraction of $10 \%$ as not infringing the said limitation of a small portion. ${ }^{36}$

In legal scholarship, some authors draw a line at $20 \%$ of a work, ${ }^{37}$ while others use a more flexible demarcation: if the portion reproduced can substitute the entire work, then it exceeds a small portion. ${ }^{38}$ According to these opinions, we are dealing with lawful conduct in our

33 It is noteworthy that the legislature is less restrictive for purposes of one's own scientific research. According to Section 52a (1) no. 2 German Copyright Act portions of a work may be reproduced or made available. Section 52a (1) no. 1 allows only small portions.

34 The EUCD pertains to "direct or indirect, temporary or permanent by any means and in any form, in whole or in part", cf. Art. 2 EUCD.

35 Generally, under German Copyright Law the doctrine of restrictive interpretation of exceptions and limitations applies. This doctrine of restrictive interpretation is also based on the three-step-test from Art. 9 (2) of the Berne Convention. See e.g. Decision of the German Federal Court of Justice, February 25, 1999 - I ZR 118/96, available at http://www.jurpc.de/rechtspr/19990113.htm.

36 Decision of the Appelate Court of Karlsruhe, May 27, 1987 U 31/86 „Referendarkurs“, published in Gewerblicher Rechtsschutz und Urheberrecht (GRUR) 1987, 818-822.

37 Cf. Ulrich Loewenheim, in: Gerhard Schricker, Urheberrecht, 2nd Edition, 1999, § 53 para. 31; Wilhelm Nordemann, in: Fromm/ Nordemann, Urheberrecht, 1998, § 53 para. 12.

38 Ute Decker, in: Möhring/ Nicolini, Urheberrechtsgesetz, 2nd Edition, 2000, § 53 para. 28. 
example. A more restrictive line of interpretation, however, is based on the claim that the constitutional guarantee of property protection in favor of the author leads to a fixed limit of 10 DIN$\mathrm{A} 5^{39}$ pages of literary works. ${ }^{40}$ Hence, although legal scholarship comes to diverging conclusions about the allowable scope, there is a strong tendency to consider a portion of $5 \%$ to be a small portion of a work. Therefore, the reproduction of 20 pages can be considered to be lawful according to the requirement in Section 52a (1) no. 1 German Copyright Act.

Referring to the reproduction of articles, the statutory exception in quantity is somewhat vague. The wording of Section 52a (1) no. 1 and 2 German Copyright Act is "individual contributions to newspapers and periodicals". An interpretation is that this means a certain number of copied articles shall not be exceeded. ${ }^{41}$ According to such an interpretation, it is unclear whether the professor fulfills the requirement set up by Section 52a German Copyright Act, since we do not know how many copied articles are permissible. However, it seems reasonable to apply one of the arguments that legal scholars made in order to decide what a small portion of work is, i.e. the number of copies must not substitute the purchase of the periodical ${ }^{42}$. Since usually scientific journals are very expensive, a normal student would not buy a periodical anyway, hence there is no danger of a substitutive effect. Therefore we assume that the reproduction of the articles fulfills the requirements set out in Section 52a (1) no. 1 Copyright Act, too.

b) Furthermore, the acts of the professor must be carried out for illustration for teaching in instruction or individual scientific research (Section 52a (1) no. 1 or 2 German Copyright Act). If the professor uses the texts during the seminar in the classroom, he can rely on Section 52a (1) no.1 ("for purposes of illustration in instruction"). If the texts serve as background or additional readings, the professor can also invoke Section 52a (1) no. 2 German Copyright Act ("for purposes of individual scientific research"), since he encourages and enables students to make their own scientific endeavors.

c) As the professor limits the user group to the participants of his seminar through password protection, we are dealing with a limited circle of users as required in Section 52a (1).

d) The last requirement is that the making available is necessary for the aspired use and can be justified by the pursuit of noncommercial ends. First of all, our professor derives no commercial profit from reproducing the documents and making them available. ${ }^{43}$ Thus, he acts for noncommercial purposes. Second, some scholars deny the necessity of making the work available if it can be accessed otherwise in analog or digital form without considerable effort. ${ }^{44}$ According to this view, the accessibility of the work in the library or in a book store would probably hinder the plans of the professor in our example. However, perhaps the curriculum of a university makes it necessary to make the works available electronically: In many cases a university library, for instance, does not have enough copies of a specific textbook to meet the demand of a considerable number of students enrolled in the same course.

\footnotetext{
39 About 81/4 X 5 7/8 inches.

40 Melichar, in: Schricker, supra note 37, § 46 para. 15; s. § 46 Rn. 11; Wandtke/Bullinger, Urheberrecht, 2. Edition, 2006.

41 Lüft, in: Wandtke/Bullinger, supra note 40, speaks of “a few”, § 52a, para. 7.

42 See Decker, in: Möhring/Nicolini, supra note 38, id.

43 It could be argued that the professor has an indirect commercial advantage since he does it as part of his job. However, he would receive the same salary regardless of whether he reproduces the documents or not.

44 Lüft, in: Wandtke/Bullinger, supra note 40, § 52a, para. 14, § 53, para. 26.
} 
e) Hence, the act of making the work available in step 4) is covered by the exception set up in the German Copyright Act. Thus, the reproductions in steps 1)-3) are lawful as well.

\section{Conclusion - and the Sunset Clause}

To date, the acts of our example are legal, unless we follow the most restrictive opinions of scholarship. However, section 137k of the German Copyright Act limits the applicability of the exception for research and teaching (Sec. 52a) to December 31, 2006. According to a first reading of a copyright reform bill in the German Parliament on June 29, 2006 this sunset clause might be prolonged until December 31, 2008. ${ }^{45}$

\section{Luxembourg}

\section{General}

Art. 10(1)2 of the Luxembourgian Act on Copyright, Neighboring Rights and Databases, as amended by the Act of April 18, 2004, states that the author may not forbid:

"the reproduction and the communication to the public of short fragments of works for the sole purpose of illustration for teaching or scientific research, to the extent justified by the non commercial purpose to be achieved, and provided that such use complies with good usages and that, unless this turns out to be impossible, the source, including the author's name, is indicated." 46

Hence, the only material difference in comparison with Art. 5(3)a EUCD is the restriction that only short fragments of works may be used. Stipulating that the exceptions enumerated in paragraph one shall not conflict with the normal exploitation of the work nor shall they unreasonably prejudice the legitimate interests of the author, Art. 10(2) of the Act restates steps two and three of the three step test. Presumably, the first step (requirement of a "special case") was considered unnecessary in light of the detailed (and, in the case of Art. 10(1)2, narrower) list of exceptions of Art. 10(1). ${ }^{47}$ Additionally, uses for the purposes of teaching and research are not subject to remuneration. ${ }^{48}$

\section{Permissibility of the acts in question}

The Luxembourgian Act does not define the term "reproduction", but as the statute was enacted in 2001, it is to be assumed that the expression also comprises digital reproductions. ${ }^{49}$ As to the acts of usage, the purpose of the acts and the citation of the author's name, the same applies as stated above in the country analysis of Malta.

How long "short fragments of works" may be is hard to say and might be determined by a comparison with the copyright laws of other countries. While five per cent of a textbook might constitute a short fragment, ${ }^{50}$ an entire article, irrespective of how short it is, apparently does not.

45 On the grounds that a definite evaluation of the provision was too early, the German parliament has adopted an extension of Section 52a of the German Copyright Act on June 29, 2006, which renders Section 52a valid until the end of 2008. This revision still has to be approved by the second chamber, the Federal Council.

46 Translation by the authors. The parts in italics were inserted by the 2004 Act into the original text of 2001.

47 According to Xalabarder, supra note 27, p. 26, Art. 5(3)a EUCD affords a sufficient degree of certainty so as to fulfill the requirements of the first step. Therefore, Art. 10(1) of the Luxemburgian Copyright Act, which is broader in scope than the EUCD exception, can be taken to comply with the first step, too.

48 Xalabarder, supra note 27, p. 16.

49 Accord Xalabarder, supra note 27, p. 12.

50 Cf. the situation in Germany, supra 4.2. 
Neither does, for instance, a picture, so that this category of works would entirely fall out of the exception because hardly anyone has a practical interest in using only a fragment of a picture. Hence, it is questionable whether the Luxembourgian legislature was aware of these inconsistencies, so that we cannot rule out that a Luxembourgian court would construe the exception extensively (praeter verba legis), as to encompass also entire short works. Aside from this element of uncertainty, the acts in question are permitted by the Luxembourgian law, provided that they comply with "good usages" and pass steps two and three of the three step test.

The term "good usages" is even vaguer than the three step test, and we are unable to determine how it significantly adds an additional element beyond the requirements of the three step test. As far as the latter is concerned, there is a high likelihood that the limitation of the exception to short fragments of works is sufficient to fulfill steps two and three of the test. If, however, the law is construed in a way that it permits uses of entire short works, Luxembourgian residents are confronted with the same problems - due to the vagueness of the test - as described in the analysis of the Maltese law.

\section{Conclusions}

Under Luxembourgian law, the situation regarding the permissibility of the uses in question is in one aspect less uncertain than in Malta because the additional element of "short fragments of works" most likely fulfills the three step test per se. On the other hand, the same requirement is highly problematic when applied literally, as - in our example - the acts of the professor with regard to journal articles would be illegal. However, if the law is construed so as to permit the use of entire short works, the acts of the professor would be legal.

\section{Slovenia}

\section{General}

Slovenia has implemented Art. 5(3)a EUCD only in parts: According to Art. 49 of the Slovenian Copyright and Related Rights Act of 30 March 1995 (as amended last on February 17, 2006), it is permissible to publicly perform works in direct teaching and at school events with free admission, and to rebroadcast radio or TV school broadcasts. Apart from that, the only copyright limitation potentially relevant to the present case is Art. 50 on private and other internal reproductions, which will be examined in detail below. In addition to these conditions, a modified version of the three step test (Art. 46) is applied: First, the extent of a permissible use is limited to the intended purpose; second, it must be compatible with fair practice; third, it should not conflict with the normal use of a work; and fourth, it should not unreasonably prejudice the legitimate interests of the author.

\section{Permissibility of the acts under Art. 50(2)?}

Art. 50(2), transposing in part Art. 5(2)b EUCD, states:

"A natural person shall be free to reproduce works: 1. [on paper etc.]; and 2. on any other medium if this is done for private use, if the copies are not available to the public, and if this is not done for direct or indirect economic advantage., 51

In addition, Art. 50(1) allows for no more than three copies being made, and it is also prohibited to reproduce whole books (Art. 50(4)). Thus, while the scanning of 20 out of 400 pages of a textbook and the downloading of electronic articles do not violate Art. 50(4), the deci-

51 Emphasis added. 
sive element is whether the uses our professor makes of the works are for private purposes. Certainly, uploading the files onto a web server and giving students access to them is not private use, hence the acts are outside the scope of Art. 50(2) (regardless of the question whether giving online access to students via passwords is a case of making copies available to the public in the sense of Art. 50(2)). In contrast, it would be legal for students to download the material from the web server.

\section{Permissibility of the acts under Art. 50(3)?}

Art. 50(3) of the Slovenian Copyright Act transposes Art. 5(2)c EUCD. Its relevant parts state:

"Publicly accessible [...] educational or scientific establishments shall be free to reproduce, on any medium, works from their own copies for internal use, provided that this is not done for direct or indirect economic advantage."

As in the case of Art. 50(2), no more than three copies may be made (Art. 50(1)), and the reproduction of whole books is not permitted, either (Art. 50(4)). In determining whether the provision also permits the upload of copies to a (password protected) web server, and to grant students access to it, one has to take into consideration recital 40 of the EUCD: Here, it is expressly stated that Art. 5(2)c EUCD should be strictly limited to the reproduction right and that it "should not cover uses made in the context of on-line delivery of protected works or other subject-matter." Construed in this light, Art. 50(3) of the Slovenian Act would not allow the upload of material onto a web server and to grant students access to it.

\section{Conclusions}

Of the national copyright regimes examined, the Slovenian is the most restrictive vis-àvis the uses envisaged by our professor and his students. Although the Slovenian law, too, has incorporated the three step test, there is no legal uncertainty since the acts are clearly illegal. ${ }^{52}$

\section{Denmark}

\section{General}

Denmark has an extended collective licensing system. Section 13(1) of the Danish Copyright Act on copies for educational purposes makes reference to this system, stating:

"For the purpose of educational activities copies may be made of published works and copies may be made by recording of works broadcast in radio and television provided the requirements regarding extended collective license (sic!) according to section 50 have been met. The copies thus made may be used only in educational activities comprised by the agreement presumed in section $50 ., 53$

\section{Collective Licensing}

These extended collective licenses are negotiated between Collective Management Organizations (CMOs) and user organizations. CMOs have to represent a substantial number of

52 Accord Maria Jose Iglesias, Teaching copyright exceptions in e-learning: the US TEACH Act and the European Arena, IPR Helpdesk Bulletin, n.17, Oct.-Nov. 2004, available at http://www.ipr-helpdesk.org/newsletter/17/ html/EN/IPRTDarticleN1045D.html.

53 Official translation by the Danish Cultural Ministry, The Act on Copyright, cf. Consolidated Act No. 618 of June 27, 2001, as amended by Act No. 1051 of December 17, 2002, available at http://www.kum.dk/ sw4550.asp. Emphasis added. 
rightsholders of a certain category of works which are used in Denmark (Section 50 (1)) ( $^{54}$ and must be approved by the Danish Ministry of Culture (Section 50 (3)) ${ }^{55}$. The agreements give users the right to exploit the works of represented and unrepresented rightsholders (Section 50 $(1))^{56}$

Copy-Dan Writing is such a CMO. ${ }^{57}$ The Society enters into and manages licensing agreements on the right to copy excerpts of printed media for use in schools, commercial schools, upper secondary schools, teacher training colleges, universities, colleges and other educational institutions as well as in businesses. ${ }^{58}$ Next to licenses for paper copies, Copy-Dan Writing is in charge of offering licenses for the scanning and digital reproduction of copyrighted material. $^{59}$

However, so far there has been no such agreement on a license for digital copying in universities and schools, and observers consider it improbable that there will be such a license in the near future. An extended license was only agreed upon for the use of works on the internet in teachers' colleges, ${ }^{60}$ and includes activities such as photocopying, scanning, printing, storage, sending by e-mail, reproduction on a password-protected Intranet, and downloading. According to this license, educators and students may copy a maximum of $20 \%$ or 30 pages of a work, whichever is less. ${ }^{61}$

\section{Permissibility of the acts in question}

In our example, the professor cannot rely on any licenses according to Section 50 Danish Copyright Act, since he neither works in a teachers' college nor took any documents from the internet. $^{62}$ Thus, his only option is to seek permission from each rightsholder individually.

\section{Conclusion}

In the absence of a collective license for the reproduction of digital works within universities, the acts performed by the professor in our example are illegal. Since the exceptions set out in Art. 5 (2)c and 5 (3) a EUCD are not obligatory, this current status does not necessarily have to change.

54 Anders Kristian Rasch, The extended collective license in Denmark, Powerpoint Presentation, Copy-Dan available at http://www.copydan.dk/upload/extended_collective_licence.ppt.

55 Id.

56 This is the reason why the system is called extended collective licensing.

57 Copy-Dan Tekst \& Node, more information available at http://www.copydan.dk/.

58 Copy-Dan according to their own presentation available at http://www.copydan.dk/Home_UK/ Writing.aspx.

59 Short Presentation of Copy-Dan Writing available at http://www.copydan.dk/upload/tn-presentation.ppt.

60 License by Copy-Dan for "seminarier”, available at http://www.copydan.dk/Unlisted_pages/Tekst_Node/ Grundaftale_eksempel.aspx.

61 Copyright and the Educational Use of Internet Content, Working Group's Report, Annex G, Modified Proposal by the Educational Sector, available at http://strategis.ic.gc.ca/epic/internet/incrp-prda.nsf/en/rp01131e.html, id., Overview of the International Context, The European Union Approach, available at http://strategis.ic.gc.ca/epic/ internet/incrp-prda.nsf/en/rp01119e.html\#3_4. This agreement raises the interesting question of how to treat content that is published online with the intention of free use without an accompanying license agreement such as a Creative Commons license, for example.

62 The professor could invoke the right to make a private copy according to Section 12(1) when scanning and storing the textbook and the articles on his workstation. However, he is not allowed to use these copies afterwards for different purposes. Also, it is doubtful whether the making of such a copy during his working hours can be considered for noncommercial purposes. 


\section{Policy Questions ${ }^{63}$}

\section{The case scenario revisited}

The scenario developed in section 2 illustrates that the "off-line" distinction between classroom teaching and distance learning is no longer valid: With the internet becoming more and more ubiquitous in our lives, "blended learning" 64 such as in our example, which combines elements of classroom and distance education, will become even more popular in the near future. It is noteworthy that this method has been shown to enhance the learning experience of students. ${ }^{65}$ Therefore, a copyright regime which facilitates blended learning has a direct effect on the quality of higher education in Europe.

Against this normative background, a couple of policy questions will be asked in the following subsections, which might serve as a starting point for discussion and more in-depth research.

This being said, two important caveats need to be made: First, when discussing policy issues, one has to bear in mind that the actual educational use of content is also affected by factors other than the design of copyright law. The emergence of new business models, ${ }^{66}$ the impact of social norms (peer production of knowledge, etc.), technical protection measures, or open access policies $^{67}$ have an impact on the use of works in education as well. These phenomena must be included in policy considerations. Second, empirical evidence of how stakeholders actually experience and observe educational exceptions to copyright might be indispensable for a normative assessment of that legislation, too.

\section{Do the implementations achieve sufficient legal certainty?}

Even a rough application of the national copyright provisions to our case scenario reveals that it is not straightforward to assess the permissibility of certain acts. This is mainly due to

63 These policy issues are of a preliminary nature since more case studies are planned.

64 See e.g., Alice Mitchell/ Carol Savill-Smith, The use of computer and vidoe games for learning, available at http://www.lsda.org.uk/files/PDF/1529.pdf.

65 See e.g. DeLacey, B. J., \& Leonard, D. A. (2002). Case study on technology and distance in education at the Harvard Business School. Educational Technology and Society, 5(2), 13-28.

66 Equitable design of copyright limitations for teaching must take account of the business interests that are involved in the reproduction and making available of works over the internet. The actual policy followed by commercial publishers is very much affected by the market that exists for copyrighted works in the educational sector. The very profitable business of scientific publishing is illustrated, for example, by the Annual Review and Summary Financial Statements 2005 of Reed Elsevier, available at http://www.reedelsevier.com/media/pdf/ 8/7/FINAL_Reed Review2.pdf, see e.g., p. 20 or OECD Report on Scientific Publishing "Digital Broadband Content: Scientific Publishing", September 02, 2005, DSTI/ICCP/IE(2004)11/FINAL, available at http://www.oecd.org/dataoecd/42/12/35393145.pdf.

67 An increasingly popular position in this context is ultimately that access to scientific work should be free. Under the European copyright regime this is currently only possible in an Open Access realm, where authors opt to publish their works over the internet (aka Green Road to Open Access). This may result from individual belief in Open Access or more or less subtle coercion. The German Research Foundation (DFG) has adopted an Open Access Policy as well. However it does not oblige the recipients of research grants to publish according to the Open Access Principles. See SPARC Open Access Newsletter, issue 96, available at http://www.earlham.edu/ peters/fos/newsletter/04-02-06.htm. 
vague language $^{68}$ including the direct implementation of the three-step test. ${ }^{69}$ It seems probable that many educators face the same difficulties when they have to predict whether a certain use is allowed or not. ${ }^{70}$ Even if emerging case law may yield more clarity in the future, ${ }^{71}$ a certain amount of legal uncertainty is likely to remain.

One of the root causes for this can be traced back to the structure of the directive itself, since the relationship between the exceptions in Art. 5(2) and (3) EUCD and the three-step test in Art. 5 (5) EUCD is unclear: The question is whether member states would have been allowed to implement the exceptions to the maximum extent outlined in Art. 5(2) and (3) EUCD without overlaying the three-step test, or, whether they were required to impose further restrictions on the single exceptions. ${ }^{72}$ Besides, this uncertainty for the legislature has also a detrimental effect on the ability to test whether national implementations are in line with the $\mathrm{EUCD}^{73}$.

\section{Did the EUCD achieve its goal to harmonize copyright law?}

As the title of the EUCD indicates and recitals 1, 3, 4, 6, 23 and 31 reiterate, harmonization of the heterogeneous copyright regimes in EU member states was the main objective of the directive. $^{74}$ On the basis of our comparison we can conclude, however, that significant differences still remain ${ }^{75}$ : For instance, while Luxembourgian law permits the acts performed by our professor, his actions would be illegal in Slovenia. ${ }^{76}$ The current lack of harmonization raises particularly tricky questions where students attend an educational institution non-resident from another country, as envisioned by various EU initiatives. ${ }^{77}$

\section{What copyright exceptions can users invoke?}

In practice the extent to which third-party content use is actually allowed by the statutory exemptions is of great relevance. We would like to point out some policy issues that arise when it comes to the scope of use in digital learning granted by the different Member countries.

68 See e.g., Germany on the question of how much of a work may be copied, Section 4.2.2.

69 See e.g., Malta, Section 4.1.3.

70 Overall, this does not apply to all national exceptions. In some cases like in Slovenia, for example, the copyright Act forbids unambiguously the making available of works for purposes of education.

71 At this stage, the existing case law has been omitted from the analysis.

72 Senftleben (supra note 31, at 259, 267, 269, 277) suggests, for example, that equitable remuneration is required in Art. 5 (3)a by the three-step test in Art. 5 (5) EUCD.

73 Objections to whether a Member State has transposed the EUCD correctly have to be pursued by taking legal action before the European Court of Justice, see, e.g., Michael Hart, The Copyright in the Information Society Directive: An Overview, European Intellectual Property Review (EIPR) 2002, 58, 61; Jörg Reinbothe, EGRichtlinie zum Urheberrecht in der Informationsgesellschaft, GRUR Int. 2001, 733, 740.

74 Senftleben, supra note 31, 253.

75 This was predicted by many commentators due to the fact that the exemptions in the directive are optional. See, e.g. Cohen Jehoram, European Copyright Law - Ever More Horizontal, International Review of Industrial Property and Copyright Law (IIC) 2001, 532, 542; Reto Hilty, Intellectual Property and the European Community's Internal Market Legislation - Copyright in the Internal Market, International Review of Industrial Property and Copyright Law (IIC) 2004, 760, 766.

76 Cf Luxembourg at 3.6 b) and Slovenia at 3.7 a) and b).

77 See, e.g., EUROPACE, information available at http://www.europace.org/portal/index.html. The HECTIC Report refers to "virtual mobility" and to the concept of a Virtual European University, Chapter 6, at 3. 


\section{Is the scope of permissible uses adequate?}

Particular national statutory exemptions seem to have created a problematic scope of permissible use. We will address some of the deficiencies below:

In the case of Luxembourg, the law does not distinguish between different types of (literary) scientific works and, at the same time, only allows the circulation of excerpts of works. ${ }^{78}$ By not taking into account the different types (and sizes) of works and their usage in teaching and research, the Luxembourgian law practically excludes journal articles and similar works from the privileges for research and education. Given the huge significance of these categories of works, this policy seems hardly perspicuous.

Less problematic, but still potentially harmful, is the scope of permissible use in Denmark's extended collective license for teachers' colleges: Here, the scope of permissible use is limited to $20 \%$ or 10 pages, whichever is less. ${ }^{79}$ This restriction might have been able to draw a consensus in the licensing negotiations. Yet, such limitations hardly create good conditions for education, as it is questionable if such a blanket restriction to ten pages is enough to allow a meaningful use of texts in the education of teachers.

Slovenian copyright law essentially prohibits the making available of works or excerpts on eLearning platforms, thus creating a serious impediment to the adaptation of such technologies and to the development of new teaching and learning methods in general-which seems rather short-sighted. ${ }^{80}$

\section{How effective are the legal techniques of transposition?}

Policy makers not only face the challenge of devising just and equitable rules that balance the various stakeholder interests, but they should no less keep an eye on the legislative technique by which they implement these rules. The different mechanisms employed by European legislatures raise a couple of normative issues, which are related to the three-step test, the relationship between fair dealing and statutory exceptions, and collective licensing. These considerations can serve as a basis for further analysis of how useful the different national copyright regimes will be for fostering online education and digital learning.

\subsection{Direct application of the three-step test}

Three out of five of our selected countries have implemented the three-step test of Art. 5(5) EUCD directly, though with slight variations in wording. ${ }^{81}$ As discussed with the example of Malta, the direct application of the three step test (Art. 5 (5) EUCD) on a case-to-case basis may result in considerable legal uncertainty. This results from the fact that the three-step test originates from non-self-executing international conventions and was designed to provide guidance to the drafting of national copyright exceptions and limitations. ${ }^{82}$

78 See at 3.6.

79 See supra note 60.

80 See also Hilty, supra note 75, IIC 2004, 760, 766.

81 Sec. 9(3) Maltese Copyright Act; Art. 10(2) Luxemburgian Copyright Act; Art. 46 Slovenian Copyright Act.

82 The three step test originates from Art. 9(2) of the Berne Convention, where it is only applicable with respect to reproductions of works. Art. 13 TRIPS and Art. 10 of the WIPO Copyright Treaty (WCT) have taken over the test and extended its scope of application to all limitations and exceptions to the rights granted under the WCT, the Berne Convention, and TRIPS. The incorporation of the three step test in Art. 5(5) of the EUCD is in line with the original purpose of the test and was probably deemed necessary since the existing limitations in Art. 
Therefore, the test might not be apt to be applied on a case-by-case basis, even when interpreted thoughtfully ${ }^{83}$ : For instance, step one does not make sense when applied to a particular use of a work, and consequently, the Luxembourgian law-in contrast to the Maltese and the Slovenian law-abstains from restating it. Also, a case-based application of step three does not make much sense, as one would have to consider the economic effects of a copyright limitation as a whole, not only in the case at hand.

Hence, a preliminary conclusion would be that the three-step test is more effective as a benchmark, against which copyright limitations can be designed within the limits of Art. 5(2) and (3) EUCD. ${ }^{84}$ In contrast, leaving this discretionary task up to the courts might result in less predictability. Where courts are confronted with the three-step test codified in a national copyright statute all the same, it is recommended that the test only be used as a basis for the (restrictive) interpretation of copyright limitations, but that it not be applied in combination with a statutory exception.

\subsection{Fair dealing and statutory exceptions}

In their provisions regarding the three-step test, the Luxembourgian and the Slovenian Copyright Acts refer to "good usage" (bon usage) and "fair practice". These terms are semantically very close to the concepts of fair dealing/fair use of Anglo-American copyright law. Hence, they could be seen as indicators of a tendency to include elements of a fair dealing or fair use exception in a (continental) copyright regime with clearly defined statutory exceptions, ${ }^{85}$ and might be accompanied by phenomena such as less legal certainty and overly cautious user behavior. $^{86}$ Then again, they have the potential to lead to a more flexible application of exceptions, as courts are confronted with uses enabled by new technologies. ${ }^{87}$ Generally speaking, it is doubtful

5(2) and (3) are comparatively broad and might have otherwise been considered to be in violation of the WCT and TRIPS. It is also described as an additional control mechanism, see Senftleben, supra note 31, p. 254.

83 This argument is further corroborated by the WTO Panel Report in the case of "United States - Section 110(5) of the US Copyright Act”, WT/DS160/R, 15 June, 2000, concerning Art. 13 TRIPS:

Step 1: "[...] a limitation or exception in national legislation should be clearly defined and should be narrow in its scope and reach. On the other hand, a limitation or exception may be compatible with the first condition even if it pursues a special purpose whose underlying legitimacy in a normative sense cannot be discerned." WT/DS160/R, 15 June, 2000, para. 6.112.

Step 2: "[Condition 2 is not met,] if uses, that in principle are covered by [copyright] but exempted under the exception or limitation, enter into economic competition with the ways that right holders normally extract economic value from [... the copyright] and thereby deprive them of significant or tangible commercial gains.” WT/DS160/R, 15 June, 2000, para. 6.183.

Step 3: "[Condition 3 is not met,] if an exception or limitation causes or has the potential to cause an unreasonable loss of income to the copyright owner." WT/DS160/R, 15 June, 2000, para. 6.229.

84 Bernt Hugenholtz, The implementation of the Directive 2001/29/EC in the Netherlands, Revue Internationale du Droit d'Auteur, 2005-2006, p.117-147.

85 Similarly Iglesias, supra note 52. In fact, the notion of an open-ended norm modelled on the US fair use doctrine influenced the deliberations in the European Parliament after the Commission had handed in its proposal; see Senftleben, supra note 31, p.249.

86 As indicated by the Brennan Report on Fair Use, Will Fair Use Survive? Free Expression in the Age of Copyright Control, Marjorie Heins \& Tricia Beckles, December 2005, available at http://www.fepproject.org/ policyreports/WillFairUseSurvive.pdf.

87 Thomas C. Vinje, Should We Begin Digging Copyright's Grave?, European Intellectual Property Review (EIPR) 2000, 551, 554. 
whether these fair use elements will shift the tradition of predefined statutory exemptions in European civil law countries. $^{88}$

\subsection{Collective licensing}

Besides fair dealing rules and statutory copyright exceptions, collective licensing-as practiced in Denmark ${ }^{89}$ — could be seen as a "third way" of enabling educational institutions to use copyright works to a reasonable extent and under reasonable conditions. There are some advantages to such a system: First, educational institutions could conclude license agreements tailored to their specific needs - in other words, not the government would determine what uses the users or members of an institution may or may not perform, but the institution itself, which knows their needs better than the government.

Yet there are also drawbacks to such a system: The example of Denmark has indeed shown that there is no guarantee that an agreement will eventually be reached, and it would probably be necessary for the government to grant a minimum of permissible uses to institutions. In addition, even if a license agreement is finally reached, a lengthy and dissatisfying period of legal uncertainty would prevail in the meantime.

\section{What role do and should technical protection measures play?}

An important practical issue is the enforceability of statutory copyright exceptions vis-àvis DRM: If, for instance, the articles that the professor in our example wants to copy are copyprotected, he could not benefit from a statutory teaching and research exception. With respect to such cases, Art. 6(4)1 EUCD obliges the Member States to "take appropriate measures to ensure that rightsholders make available to the beneficiary the means of benefiting from that exception or limitation." 90 These appropriate measures are mandatory for national exceptions based inter alia on Art. 5(2)c, and 5(3)a EUCD. The EUCD provides the individual Member States with quite a broad range of discretion, allowing each Member State to establish different mechanisms to ensure that rightsholders enable the benefits of the exceptions. ${ }^{91}$ For a detailed analysis of such mechanisms in selected E.U. members we refer to Urs Gasser and Michael Girsberger, "Transposing the Copyright Directive: Legal Protection of Technical Measures in EU-Member States: A Genie Stuck in the Bottle?"92

88 The Proposal of the Netherlands to introduce a fair use exception in Art. 5 EUCD found no support during the preparation of the EUCD, see Jehoram, supra note 75, IIC 2001, 532, 542. Grosheide sees in the extensive list of exceptions in the EUCD a mandatory prohibiton of introducing a general fair use exception into national law, see F. Willem Grosheide, Is the Appropriate EU Legal Framework in Place for Music Online? International Review of Industrial Property and Copyright Law (IIC) 2002, 698, 712.

89 See at $3.8 \mathrm{~b})$.

90 Art. 6 (4) EUCD continues "to the extent necessary to benefit from that exception or limitation and where that beneficiary has legal access to the protected work or other subject-matter."

91 In Germany, for instance, Section 95b (1) German Copyright Act obliges the rightholder to provide the user with the necessary means to enable the permissible use. But the law does not provide a procedure for how this should be accomplished. There is the possibility to sue the rightholder if he does not assist the user and an administrative fine is set out by Section 111a (1) no. 2 German Copyright Act. The practical relevance of these provisions is low. But, most importantly, this obligation is not valid if the work is available online via a commercial offer according to Section 95b (3). This leads to a pay-per-use situation and aggravates access for research and teaching by raising additional costs for the users.

92 Berkman Publication No. 2004-10, at 17 et seq. (conclusion at 24 et seq.), available at http://papers.ssrn.com/ sol3/papers.cfm?abstract_id=628007. 


\section{DEVISING TEACHING EXCEPTIONS AS A CONTINUING CHALLENGE}

With regard to all the issues identified in the foregoing section, we should keep in mind that methods of teaching in a networked society are still evolving and may change in unforeseeable ways and at an unpredictable pace in the coming years. We have seen that current copyright regimes in Europe still differentiate between online and offline teaching. As of today, experience shows that a curriculum may well involve both face-to-face teaching and use of online resources, and against this backdrop, a copyright regime that allows the use of paper works in the classroom but not the use of digital works on an e-learning platform already appears anachronistic. Worse, such a sclerotic regime would have great potential to compromise the quality of higher education in Europe and elsewhere, and therefore be contradictory to the official policy of the EU. ${ }^{93}$

Instead, copyright law should be flexible enough to adapt to the potential of networked learning in educational institutions, and it is high time to prepare the ground for an intellectual property regime that does not stand in the way of these factual developments. ${ }^{94}$ In doing this, copyright law would move closer to its programmatic goal as declared in the title of the Queen Anne statute of 1710: "the Encouragement of learning”.

93 Cf. e.g. the official Lisbon Agenda, supra note 7.

94 See for similar considerations with regard to the free circulation of copyrighted works, e.g., Vinje, supra note 87, EIPR 2000, 551, 554. 